Thabiea : Journal of Natural Science Teaching
Program Studi Tadris Ilmu Pengetahuan Alam
Institut Agama Islam Negeri Kudus
http://journal.stainkudus.ac.id/index.php/Thabiea
$p$-issn: 2580-8974, e-issn: 2655-898x

\title{
Pengembangan Modul Kesetimbangan Kimia Berbasis Unity of Sciences (UoS) dan Multilevel Representasi
}

\author{
Farida Septiana Wati ${ }^{\mathrm{a}, 1^{*}}$, Ulya Lathifa ${ }^{\mathrm{b}, 2}$, Wirda Udaibah ${ }^{\mathrm{c}, 3}$ \\ a,b,c UIN Walisongo Semarang, Jl. Prof Dr Hamka Ngaliyan Semarang, 50181 \\ ${ }^{1}$ faridaseptianawati88@gmail.com*; ${ }^{2}$ ulyalathifa@ walisongo.ac.id; ${ }^{3}$ wirda_udaibah@walisongo.ac.id
}

\begin{tabular}{l}
\hline Kata kunci: \\
Modul Pembelajaran; \\
Unity of Sciences; \\
Multi level Representasi; \\
Kesetimbangan Kimia
\end{tabular}

\begin{abstract}
ABSTRAK
Penelitian pengembangan ini bertujuan untuk mengetahui karakteristik dan kelayakan modul pembelajaran kimia berbasis unity of sciences dan multi level representasi pada materi kesetimbangan. Model pengembangan yang digunakan adalah 4D (define, design, develop, dan disseminate) namun hanya dilakukan sampai tahap develop. Dalam pengumpulan data digunakan metode wawancara, observasi, dokumentasi, dan tes. Hasil validasi oleh ahli materi diperoleh presentase rata-rata sebesar $87,7 \%$ dengan kategori sangat layak. Dari hasil validasi ahli media diperoeh presentase rata-rata sebesar $88 \%$ dengan kategori sangat layak, sedangkan dari penilaian peserta didik diperoleh presentase rata-rata sebesar 90,22\% dengan kategori sangat layak. Dari postes diperoleh nilai rata-rata sebesar 89,11. Dengan demikian modul kimia berbasis unity of sciences dan multi level representasi pada materi kesetimbangan kimia layak untuk digunakan sebagai sumber belajar peserta didik.
\end{abstract}

\section{Key word:}

Learning Modules;

Unity of Science;

Multi Level Representation;

Chemical Equilibrium

\section{ABSTRACT}

This development research aims to determine the characteristics and feasibility of chemistry learning modules based on unity of sciences and multi-level representation on equilibrium material. It use 4D developmental model (define, design, develop, and disseminate) but only done until the develop stage. In collecting data, the interview, observation, documentation, and test methods are used. The results of validation by the material experts obtained an average percentage of $87.7 \%$ with a very decent category. From the media expert, it was obtainned an average percentage of $88 \%$ with a very decent category, while from the assessment of students obtained an average percentage of $90.22 \%$ with a very decent category. From the posttest obtained an average value of 89.11 . Thus the chemistry module based on unity of sciences and multi-level representation on chemical equilibrium material is appropriate for use as a learning resource for students.

Copyright (C) 2019 Institut Agama Islam Negeri Kudus. All Right Reserved

\section{Pendahuluan}

Peningkatan kualitas pendidikan merupakan konsen setiap bangsa, termasuk Indonesia. Oleh karena itu, setiap bangsa merumuskan tujuan pendidikan nasional. Tujuan pendidikan Indonesia yang tertuang dalam Pasal 3 UU No 20 Th 2003 antara lain mengembangkan potensi yang ada dalam setiap peserta didik sehingga dapat menjadi manusia yang beriman serta bertakwa kepada Tuhan YME, menjadi manusia yang sehat jasmani dan rohani, memiliki akhlak yang mulia, berilmu, sophisticated, kreatif, dan tanggung jawab (Pemerintah Republik Indonesia, 2003). Salah satu wujud dari tujuan pendidikan adalah adanya pembentukan kurikulum yang terimplementasikan secara nasional. Kurikulum disebut Perdana (2016) sebagai suatu langkah yang ditempuh guna memantapkan desain pembelajaran dalam suatu proses belajar mengajar. Kurikulum yang diberlakukan di Indonesia sekarang ini 
adalah kurikulum 2013 revisi. Kurikulum tersebut terdiri dari beberapa kompetensi inti yang wajib dikuasai peserta didik. Kompetensi inti tersebut antara lain kompetensi inti sikap spiritual, sosial, pengetahuan dan keterampilan.

Namun, implementasi kompetensikompetensi inti tersebut banyak menghadapi kesulitan terutama pada aspek sikap spiritual. Pada dimensi spiritual guru diharapkan mampu melakukan kontemplasi nilai-nilai keIlahian terhadap pembelajaran yang dilakukan, termasuk kimia. Pada kenyataannya, banyak guru kimia yang belum mampu menerapkannya (Zain \& Vebrianto, 2017).

Hasil riset pendahuluan yang dilaksanakan di SMA Negeri 2 Semarang menunjukkan bahwa konsep pengintegrasian nilai-nilai Islam terhadap ilmu kimia belum dilakukan oleh guru. Meskipun guru telah mengintegrasikan kimia dengan ilmu-ilmu lain seperti fisika dan biologi, namun sentuhan Islami di dalam pembelajaran belum dilakukan. Hal tersebut tentunya menjadikan aspek spiritual dalam kompetensi inti 1 belum tercapai dengan baik.

Selain KI 1, kompetensi lain yang perlu dikuasai yaitu aspek pengetahuan (KI 3). Kompetensi ini menuntut peserta didik mampu memahami materi serta mengaplikasikannya. Meskipun KI 3 menjadi perhatian bagi seluruh pengajar, namun kendala-kendala masih sering ditemui. Kendala tersebut salah satunya berasal dari karakteristik ilmu kimia. Ilmu kimia hadir dengan banyak konsep yang abstrak (Taber, 2002; Sirhan, 2007; Berrewinkel, Parchmann, \& Grasel, 2010). Adanya keabstrakan konsep tersebut menjadikan kimia sulit dipahami oleh peserta didik (Demircioglu et al., 2013). Untuk memvisualisasikan konsep yang abstrak, ilmu kimia perlu diajarkan dengan melibatkan multipel representasi (Wulandari, Susilaning, \& Kasmui, 2018). Multipel representasi merupakan representasi berlangsungnya proses kimia dan entitas seperti atom dan molekul yang melibatkan rumus, simbol, serta struktur.
Pengembangan pemahaman konsep dasar kimia dapat dilakukan dengan menanamkan level-level representasi pada peserta didik, yaitu level makroskopik, submikroskopik dan simbolik (Becker et al, (2015). Level makroskopik merupakan penjelasan terhadap segala sesuatu yang dapat ditangkap oleh pancaindera. Level submikroskopik merupakan representasi terhadap senyawasenyawa/ proses kimia yang tidak kasat mata melalui pemodelan, sedangkan level simbolik merupakan perlibatan rumus dan simbolsimbol untuk merepresentasikan senyawa, unsur dan molekul serta reaksi kimia. Cakupan konsep berkenaan denagn komponen larutan, konsentrasi, serta sifat asam basa pada larutan berair sering diajarkan hanya sebagai hafalan dan perhitungan matematis, tanpa memperhatikan aspek submikroskopik pada jenjang level sekolah (Imaduddin, 2018). Dengan adanya representasi yang tepat maka pemahaman konseptual yang utuh dapat dimiliki peserta didik.

Berdasarkan hasil try out materi kimia yang memuat konten representasi kimia pada kelas XI di SMA N 2 Semarang, diketahui hanya $12 \%$ peserta didik yang mampu menghubungkan konsep kimia dalam ketiga level representasi kimia. Hasil wawancara juga menunjukkan bahwa pembelajaran di kelas hanya menekankan pada aspek makroskopik dan simbolik. Hal tersebut tentunya menjadikan proses konstruksi konsep terhambat.

Salah satu materi yang diajarkan di kelas XI adalah kesetimbangan kimia. Materi tersebut mencakup jenis-jenis kesetimbangan reaksi dan faktor-faktor yang mempengaruhinya. Sebagai materi wajib, peserta didik diharapkan menguasi materi tersebut. Namun berdasarkan hasil penyebaran kuesioner diketahui sebanyak $57 \%$ peserta didik mengalami kesulitan pada materi tersebut. Hal tersebut dibuktikan dengan sebanyak $51,28 \%$ peserta didik belum mencapai nilai ketuntasan minimal. 
Salah satu solusi yang dapat ditawarkan adalah dengan merencanakan dan melaksanakan pembelajaran terintegrasi nilainilai keagamaan (unity of sciences) dan berbasis multilevel representasi. Unity of sciences merupakan suatu konsep yang berupaya menghilangkan dikotomi ilmu agama dan ilmu umum dikarenakan keseluruhan ilmu bersumber dari Tuhan YME (Nirwana \& Fitriyana, 2018). Pembelajaran dapat berjalan dengan maksimal jika pembelajaran didasarkan pada karakteristik ilmu kimia, yaitu mengajarkan konsep berbasis multilevel representasi (Aliyah, dkk., 2018). Konsep Unity of sciences mampu mengakomordir pencapaian KI-1 sedangkan konsep multilevel representasi bisa mengakomodir KI-3.

Di dalam pembelajaran kimia, peserta didik kelas XI SMA N 2 Semarang menggunakan sumber ajar berupa buku paket serta Lembar Kerja (LK) yang disusun oleh pengajar. Namun di dalam pembelajaran, sumber ajar yang dominan digunakan adalah Lembar Kerja (LK). Hal itu dikarenakan buku paket merupakan buku pinjaman dari perpustakaan sehingga peserta didik mendapatkan buku paket yang berbeda penerbit. Hal tersebut menjadikan guru kesulitan dalam menyamakan materi ajar karena buku dengan berbeda penerbit memiliki kedalaman serta konteks yang berbeda.

Untuk mengatasi keterbatasan sumber ajar dan pemenuhan KI 1 serta KI 3 maka perlu dikembangkan suatu sumber ajar yang mampu mengakomodir permasalahan tersebut. Salah satu solusi yang dapat dilakukan adalah dengan mengembangkan modul pembelajaran berbasis multilevel representasi dan unity of sciences. Mulyasa (2004) menyatakan bahwa modul merupakan bahan belajar mandiri yang melibatkan serangkaian pembelajaran yang disusun secara sistematis agar peserta didik dapat mencapai tujuan dan indikator pembelajaran. Pengembangan modul sebagai solusi masalah juga diperkuat berdasarkan angket yang diberikan, di mana $78,2 \%$ peserta didik bergaya belajar visual sedangkan $65 \%$ belajar secara mandiri.

\section{Metode}

Penelitian ini merupakan Research and development. Model pengembangan yang digunakan dalan penelitian ini adalah 4-D (Four-D Model) yang terdiri dari 4 tahap pengembangan yaitu Define, Design, Develop, dan Disseminate (Thiagarajan et al., 1974). Akan tetapi dalam penelitian ini hanya sampai tahap develop karena keterbatasan peneliti. Tujuan penelitian ini adalah menghasilkan modul yang berbasis unity of sciences dan multi level representasi pada materi kesetimbangan kimia.

Penelitian ini dilaksanakan di SMA N 2 Semarang. Subjek penelitian ini adalah peserta didik kelas XII yang telah mendapatkan materi kesetimbangan kimia. Pengambilan data dilakukan dengan wawancara, angket, dokumentasi, dan tes. Modul divalidasi oleh validator ahli materi dan media. Peserta didik sebanyak 9 orang juga dimintai respon terhadap modul yang dikembangkan.

\section{Hasil dan Pembahasan}

Pengembangan modul kimia berbasis unity of sciences dan multi level representasi pada materi kesetimbangan diawali dengan observasi di SMA N 2 Semarang. Sumber belajar yang dominan digunakan dalam proses pembelajarannya adalah LKS. Sumber belajar yang digunakan guru dan peserta didik tersebut baik materi, contoh soal maupun latihan belum berbasis unity of sciences dan multi level representasi.

Model pengembangan modul yang digunakan adalah pengembangan menurut Thiagarajan, et al. (1974) terdiri dari 4 tahap. Tahapan awal dalam pengembangan ini adalah define. Tahap ini melibatkan 5 langkah yang terdiri dari analisis ujung depan (front-end analysis), analisis peserta didik (learner analysis), analisis konsep (concept analysis), analisis tugas (task analysis) dan perumusan 
tujuan pembelajaran (specifying instructional objectives). Tahap tersebut sebagai acuan dasar desain dan pengembangan modul pembelajaran.

Pengembangan modul kimia berbasis unity of sciences dan multi level representasi pada materi kesetimbangan kimia di awali dari penentuan kebutuhan peserta didik. Sebanyak 57\% peserta didik menyatakan bahwa materi kesetimbangan dianggap sulit. Pada tahap define, dirumuskan solusi pengembangan modul sebagai sumber belajar mandiri sehingga tujuan pembelajaran dapat tercapai. Hal ini sesuai dengan pernyataan Daryanto (2013) yang menyebutkan bahwa salah satu bahan ajar yang dikemas secara utuh dan sistematis, yang di dalamnya memuat seperangkat pengalaman belajar yang terencana dan didesain untuk membantu peserta didik menguasai tujuan belajar yang spesifik merupakan modul pembelajaran. Andi (2011) juga mengatakan bahwa pengembangan modul bertujuan agar peserta didik dapat belajar secara mandiri dalam suatu rangkaian materi.

Pada tahap design, pemilihan modul didasarkan pada analisis kebutuhan peserta didik di mana sebanyak $78,2 \%$ memiliki gaya belajar visual. Pada tahap develop dilakukan validasi oleh ahli materi dan media untuk menghasilkan modul yang layak dalam proses pembelajaran. Adapun grafik hasil kualitas modul pembelajaran berdasarkan ahli materi dapat dilihat pada Gambar 1.

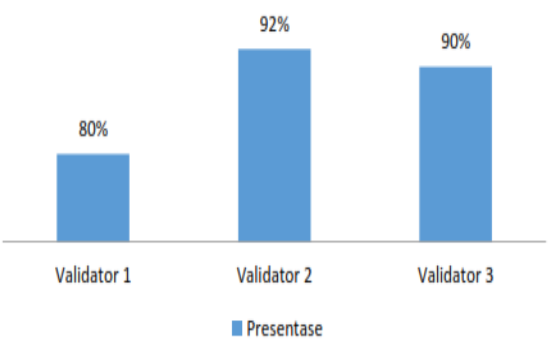

Gambar 1. Skor Validasi Ahli Materi

Berdasarkan grafik pada Gambar 1 diketahui bahwa hasil presentase kelayakan modul oleh ahli materi untuk validator 1 yaitu
80\% dengan kategori cukup valid. Dari validator 1 terdapat beberapa perbaikan seperti perbaikan pada penulisan wujud materi, pemvariasian soal evaluasi, dan perbaikan kontemplasi kimia-nilai spiritual dengan lebih mengintegrasikan ayat-ayat al-Qur'an pada materi kesetimbangan kimia. Kontemplasi kimia-nilai spiritual dengan mengintegrasikan ayat-ayat Al-Qur'an sebagai aspek unity of sciences ditujukan agar peserta didik lebih jelas mengetahui bagaimana terjadinya fenomena kesetimbangan oksigen di dalam darah. Apabila langsung bersumber dari ayatayat Allah (ayatisasi), maka dirasa sulit bagi peserta didik untuk mengkonstruk konsep. Fanani (2015) menyatakan kontemplasi kimiaislam yang mengintegrasikan ayat-ayat Allah dapat membangun ilmu pengetahuan baru yang didasarkan pada kesadaran kesatuan ilmu yang kesemuanya bersumber dari ayat-ayat Allah.

Validasi oleh validator 2 memperoleh presentase $92 \%$ yang termasuk kategori sangat valid. Terdapat saran dari validator untuk perbaikan, yaitu perbaikan jumlah molekul dari peruraian gas $\mathrm{SO}_{3}$ menjadi $\mathrm{SO}_{2}$ dan $\mathrm{O}_{2}$, dan perbaikan gambar submikroskopik perubahan tekanan dan volume. Validator 3 memberikan presentase kelayakan modul sebesar 90\% kategori sangat valid. Berdasarkan presentase kelayakan yang diperoleh dari validator materi, modul yang dikembangkan sudah memenuhi kriteria baik dari aspek kelayakan isi, aspek kebahasaan, aspek teknik penyajian, aspek unity of sciences maupun aspek multi level representasi kimia.

Hasil presentase kelayakan modul oleh ahli media didapatkan presentase kelayakan $88 \%$ dengan kategori sangat valid. Berdasarkan presentase tersebut diketahui bahwa modul yang dikembangkan sudah memenuhi aspek kriteria yang ditetapkan dalam instrumen validasi ahli media baik dari aspek penyajian modul, aspek kelayakan kegrafikan maupun aspek kualitas tampilan. Berdasarkan pada penilaian secara keseluruhan dari validator ahli media dan materi, dapat 
disimpulkan modul pembelajaran kimia berbasis unity of sciences dan multi level representasi kimia layak digunakan dalam uji coba kelas kecil.

Setelah dilakukan validasi, modul yang dikembangkan diujicobakan pada kelas kecil. Peserta didik diminta untuk memberikan tanggapan. Hasil penilaian peserta didik terhadap modul dapat dilihat pada Gambar 2.

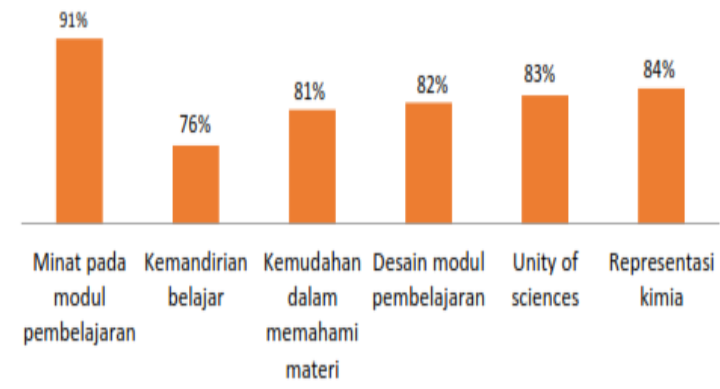

Gambar 2. Grafik Tanggapan Peserta Didik

Dari Gambar 2 diketahui bahwa presentase minat peserta didik terhadap modul pembelajaran sebesar $91 \%$. Hal tersebut menunjukkan bahwa peserta didik menyukai dan tertarik terhadap modul pembelajaran. Wardiana (2005) menyatakan bahwa minat dalam proses belajar mengajar merupakan salah satu faktor yang besar pengaruhnya terhadap prestasi belajar. Peserta didik yang memiliki minat belajar tinggi akan melakukan kegiatan lebih banyak dan lebih cepat, dibandingkan dengan peserta didik yang kurang termotivasi dalam belajar.

Peserta didik memberikan penilaian aspek kemandirian belajar pada modul rata-rata sebesar $76 \%$. Hasil tersebut menunjukkan bahwa sebagian besar peserta didik dapat menggunakan modul dengan mudah dan dapat mempelajarinya dimanapun dan kapanpun. Dengan demikian dapat dikatakan bahwa hasil dari pengembangan modul telah memenuhi syarat dari modul yang baik. Menurut Budiono \& Susanto (2006) modul yang baik adalah modul yang dapat digunakan secara mandiri oleh peserta didik dalam pembelajaran baik tanpa atau dengan bimbingan pendidik.

Aspek kemudahan dalam memahami materi diberikan penilaian sebesar $81 \%$. Hal ini menunjukkan bahwa penyajian materi yang terdapat dalam modul mudah dipahami peserta didik. Hal itu dikarenakan uraian, contoh dan latihan soal yang disajikan dalam modul dikaitkan dengan kehidupan sehari-hari dan terdapat visualisasi berupa gambar-gambar sehingga menarik bagi peserta didik. Kemudahan peserta didik dalam memahami materi dapat dilihat dari kemampuan peserta didik dalam mengerjakan evaluasi yang disajikan di dalam modul. Sebagai contoh, pada soal nomor 2 kemampuan representasi peserta didik mengalami peningkatan dari yang semula $12 \%$ (pretes) menjadi $77,7 \%$ (postes). Pada soal nomor 2 peserta didik diminta untuk memilih gambar submikrokopik ketika larutan $\mathrm{NaOH}$ bereaksi dengan $\mathrm{HCl}$. Untuk mengerjakan soal tersebut peserta didik harus mengetahui fenomena makroskopik yang terjadi dalam larutan terlebih dahulu, kemudian menuliskan reaksi yang terjadi. Setelah itu, peserta didik dapat mengerjakan aspek submikroskopik hasil reaksi yang terjadi di dalamnya. Peningkatan pemahaman materi sebesar $62,7 \%$ menandakan peserta didik mudah memahami materi yang disajikan dalam modul dan sudah mulai beradaptasi dengan bentuk soal dalam modul yang berbasis multipel representasi.

Aspek yang menjadi karakteristik modul yaitu unity of sciences mendapat nilai rata-rata sebesar 83\%. Hasil tersebut menunjukkan peserta didik lebih mudah pada materi yang disajikan dengan konten unity of sciences. Konten unity of sciences disajikan dengan mengintegrasikan Islam serta menghubungkannya dengan kehidupan seharihari. Asfiah, Mosik, Purwantoyo (2013) menyatakan bahwa modul yang disajikan dengan memberikan contoh yang berkaitan dengan kehidupan sehari-hari, mampu menjadikan peserta didik mengaitkan materi dengan kehidupan nyata dan dapat memotivasi peserta didik dalam belajar.

Aspek multilevel representasi diberikan nilai rata-rata sebesar $84 \%$ yang terkategori baik. Hasil tersebut menunjukkan sebagian 
besar peserta didik paham pada materi yang dikaitkan dengan tiga level representasi kimia. Hal tersebut dikarenakan pembahasan materi dalam modul diawali gambar yang jelas dari makroskopik direpresentasikan ke submikroskopik dan simbolik. Tasker \& Dalton (2006) menyatakan bahwa pembelajaran kimia umumnya menggunakan level makroskopik dan level simbolik, sehingga akan terjadi kesalahpahaman dalam pembelajaran kimia berasal dari ketidakmampuan peserta didik untuk memvisualisasikan struktur dan proses dalam level submikroskopik (tingkat molekul). Jadi, penggunaan ketiga representasi kimia dalam modul sangat membantu peserta didik dalam memahami konsep-konsep kimia yang sebagian besar bersifat abstrak. Pernyataan tersebut dibuktikan ketika peserta didik mengerjakan soal latihan tetapan kesetimbangan dalam modul. Mereka mampu merepresentasikan fenomena makroskopik ke dalam submikroskopik dan simbolik. Seperti contoh soal nomor 3, peserta didik mampu menyebutkan manfaat dari gas ammonia, lalu menggambarkan bentuk molekul zat yang bereaksi di dalam kesetimbangan tersebut dan merepresentasikan ke dalam simbolik.

Modul kimia berbasis unity of siences dan multi level representasi kimia yang telah dikembangkan menjadi solusi yang tepat untuk permasalahan yang dihadapi peserta didik. Hal ini dibuktikan ketika proses pembelajaran sebelum menggunakan modul, KI 1 belum terwujud. Setelah dilakukan pembelajaran menggunakan modul, diketahui KI 1 dapat terwujud. Hal itu dibuktikan dari hasil tanggapan peserta didik pada aspek unity of sciences dengan memperoleh nilai presentase sebesar $83 \%$ dan berkategori kualitas baik. Hal ini juga diperkuat dengan wawancara kepada 9 peserta didik yang mengatakan ketika modul dilengkapi dengan aspek unity of sciences membuat peserta didik menjadi semakin taat kepada Tuhan Yang Maha Esa dan lebih mensyukuri atas nikmat yang diberikan untuk manusia. Hal ini sependapat dengan Rahmah., dkk (2017) yang menyatakan bahwa pada KI 1 diharapkan mampu menumbuhkan kesadaran peserta didik akan kebesaran, kebenaran, dan kekuasan Tuhan Yang Maha Esa. Selain itu, peserta didik juga diharapkan agar dapat lebih menyadari keteraturan dan keterkaitan antara sains dan ayat-ayat al-Qur'an.

Tidak hanya itu saja modul yang dikembangkan meningkatkan kemampuan multi level representasi peserta didik, sehingga K-3 dalam kurikulum 2013 revisi terwujud. Hal ini dibuktikan dari data sebelum menggunakan modul, kemampuan multilevel representasi peserta didik $12 \%$, sedangkan setelah menggunakan modul sebesar $77,7 \%$. Peserta didik sudah mulai terbiasa menggambarkan fenomena makroskopik yang kemudian direpresentasikan ke dalam level submikroskopik. Dengan adanya modul ini peserta didik dapat belajar secara mandiri.

Selain memberikan tanggapan pada modul yang dikembangkan, peserta didik juga diberikan tes. Tes dilakukan setelah peserta didik menggunakan modul untuk mengukur ketercapaian indikator pembelajaran peserta didik pada konsep kesetimbangan kimia. Nilai rata-rata hasil tes peserta didik adalah 89,11 . Berdasarkan data nilai tes dapat diketahui bahwa indikator pembelajaran pada konsep kesetimbangan kimia dapat tercapai dengan menggunakan modul kimia berbasis unity of sciences dan multi level representasi kimia pada materi kesetimbangan kimia. Untuk perbaikan ke depan, soal latihan dalam modul berbasis multi level representasi sebaiknya diperbanyak dan divariasikan. Kegiatan praktikum juga perlu ditambahkan pada modul untuk meningkatkan kemampuan multilevel representasi peserta didik. Ktika proses pembelajaran dilakukan, peserta didik perlu memahami terlebih dahulu tentang multi level representasi dan unity of sciences. Apabila peserta didik belum memahami dua hal tersebut, maka akan merasa kesulitan dalam belajar menggunakan modul berbasis unity of sciences dan multi level representasi. 


\section{Simpulan}

Berdasarkan hasil pengembangan dan uji coba kelas kecil maka dapat ditarik beberapa simpulan. Karakteristik modul yang dikembangkan yaitu modul kimia berbasis unity of sciences dan multi level representasi pada materi kesetimbangan. Pada basis unity of sciences digunakan strategi spiritualisasi ilmu modern, yaitu menghubungkan konsep kimia dengan ayat-ayat Al-Qur'an dan fusi filosofi serta pengintegrasian nilai-nilai spiritual yang dapat meningkatkan kompetensi inti 1. Sedangkan pada basis multilevel representasi dalam kegiatan pembelajaran terdapat kolom multilevel representasi, yaitu kegiatan mengkoneksikan level makroskopik, submikroskopik dan simbolik. Latihan soal yang digunakan pada modul ini juga berbasis multilevel representasi. Tidak hanya itu saja pada level makroskopiknya terdapat aplikasi kimia dalam kehidupan sehari-hari, sehingga ilmu kimia yang bersifat abstrak lebih mudah dipahami oleh peserta didik. Modul kimia berbasis unity of sciences dan multi level representasi pada materi kesetimbangan memiliki kualitas sangat baik sebagai bahan ajar dan dapat dilanjutkan ke tahap implementasi kelas besar. Modul ini dinyatakan sangat valid oleh ahli validasi materi dengan presentase sebesar $87,7 \%$. Sementara itu hasil validasi dari ahli media diperoleh presentase $88 \%$ dengan kategori sangat valid. Hasil respon peserta didik dikategorikan sangat baik dengan skor $90,22 \%$.

\section{Referensi}

Aliyah, A.A., Susilaning, E., Kasmui, Nurchasanah, \& Astuti, P. 2018. Desain Media Peta Konsep Multi Representasi pada Materi Buffer dan Hidrolisis. Jurnal Inovasi Pendidikan Kimia, 12(1): 20552064.

Andi, Prastowo. 2011. Panduan Kreatif Membuat Bahan Ajar Inofatif. Yogyakarta: Diva Press.

Asfiah. N, Mosik \& Purwantoyo. 2013. Pengembangan Modul IPA Terpadu Kontekstual pada Tema Bunyi. Unnes Science Education Journal, 2(1): 188-195.

Becker, N., Standford, C., Towns, M., \& Cole, R. 2015. Translating Across Macroscopic, Submicroscopic, and Simbolic Levels: The
Role of Instructor Facilitation in An Inquiry-Oriented Physical Chemistry Class. Journal of Chemistry Education Research an Practice, 16: 769771.

Berrewinkel, A., Parchmann, I., \& Grasel, C. 2010. Conceptual Change Texts in Chemistry Teaching: A Study on the Particle Model of Matter. International Journal of Science and Mathematics Education, 9(1): 1235-1259.

Budiono, E. \& Susanto, H. 2006. Penyusunan dan Penggunaan Modul Pembelajaran Berdasar Kurikulum Berbasis Kompetensi Sub Pokok Bahasan Analisa Kuantitatif Untuk Soal-soal Dinamika Sederhana Pada Kelas X Semester I Sma. Jurnal Pend. Fisika Indonesia, 4(20): 79-87.

Daryanto. 2013. Inovasi Pembelajaran Efektif. Bandung: Yrma Widya.

Demircioglu, G., Demircioglu, H., \& Yadogaroglu, M. 2013. An Investigation of Chemistry Student Teachers' Understanding of Chemical Equilibrium. International Journal on New Trends in Education and Their Implication, 4(2): 192-199.

Fanani, M. 2015. Paradigma Kesatuan Ilmu Pengetahuan. Semarang: CV. Karya Abadi Jaya.

Imaduddin, M. 2018. Analisis Miskonsepsi Submikroskopik Konsep Larutan pada Calon Guru Kimia. EduSains: Jurnal Pendidikan Sains \& Matematika, 6(2): 112.

Mulyasa. 2004. Kurikulum Berbasis Kompetensi. Bandung: Remaja Rosda Karya.

Nirwana, R.R., \& Fitriyana, R. 2018. Pengembangan Modul Biomolekul dan Metabolisme dengan Paradigma Unity of Sciences dan Growth Mindset. Jurnal Phenomenon, 8(1), 83-100.

Pemerintah Republik Indonesia. 2003. Undang-Undang No 20 Tahun 2003 tentang Sistem Pendidikan Nasional. Sekretaris Negara Republik Indonesia: Jakarta

Perdana, D. I. (2016). Kurikulum Dan Pendidikan Di Indonesia Proses Mencari Arah Pendidikan Yang Ideal Di Indonesia atau Hegemoni Kepentingan Penguasa Semata? Jurnal Pemikiran Sosiologi, 2(1), 63. https://doi.org/10.22146/jps.v2i1.23412. 
Rahmah, Zainatur, S., Mulyani, S., \& Masyikuri, M. 2017. Pengembangan Modul Berbasis SETS (Science, Environment, Technology, Society) Terintegrasi Nilai Islam di SMAI Surabaya Pada Materi Ikatan Kimia. Jurnal Pendidikan. 2(1): 57-56.

Sirhan, G. 2007. Learning Difficulties in Chemistry: An Overview. Journal of Turkish Science Education, 4(2): 2-20.

Supena, Ilyas. 2014. Paradigma Unity of Sciences IAIN Walisongo dalam Tinjauan Filsafat Ilmu. Semarang: LP2M IAIN Walisongo.

Taber, K. S., (2002). Alternative Conceptions In Chemistry: Prevention, Diagnosis And Cure? London: The Royal Society of Chemistry.

Tasker, R. \& Dalton, R. 2006. Research Into Practice: Visualization of The Molecular World Using Animations. Chemistry Education Research and Practice. 7: 141159.

Thiagarajan S., Semmel, D.S., \& Semmel, M.I 1974. Instructional Development for Training Teachers of Exceptional Children. Bloomington: Indian University.

Wardiana U. 2005. Psikologi Umum. Jakarta: Bina Ilmu

Wu, H. K., Krjcik, J. S, \& Soloway, E. 2001. Promoting Understanding of Chemical Representations: Students' Use of a Visualization Tool in The Classroom. Journal of Research in Science Teaching. 38(7): 821824.

Wulandari, C., Susilaning, E., \& Kasmui. (2018). Estimasi Validitas dan Respon Siswa Terhadap Bahan Ajar Multi Representasi: Definitif, Makroskopis, Mikroskopis, Simbolik pada Materi Asam Basa. Jurnal Phenomenon, 08(2), 165174.

Zain, Z., \& Vebrianto, R. (2017). Integrasi Keilmuan Sains Dan Islam Dalam Proses Pembelajaran Rumpun IPA. Jurnal Program Studi Pendidikan Kimia, 18-19. 